Pacific Journal of Mathematics

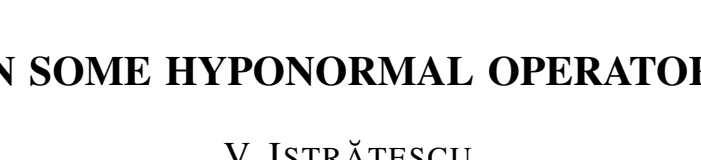




\section{ON SOME HYPONORMAL OPERATORS}

\section{ISTRĂȚESCU}

Let $H$ be a Hilbert space and $T$ a hyponormal operator $\left(T^{*} T-T T^{*} \geqq 0\right)$. The first result is: if $\left(T^{*}\right)^{p} T^{q}$ is a completely continuous operator then $T$ is normal.

Secondly, part we introduce the class of operators on a Banach space which satisfy the condition

$$
\|x\|=1 \quad\|T x\|^{2} \leqq\left\|T^{2} x\right\|
$$

and we prove the following:

1. $\gamma_{T}=\lim \left\|T^{n}\right\|^{1 / n}=\|T\|$;

2. if $T$ is defined on Hilbert space and is completely continuous then $T$ is normal.

In what follows for this section we suppose that $T$ is a hyponormal operator on Hilbert space $H$.

THEOREM 1.1. If $T$ is completely continuous then $T$ is normal.

This is known ([1], [2], [3]).

The main result of this section is as follows.

THeorem 1.2. If $T^{* p} T^{q}$ is completely continuous where $p$ and $q$ are positive integers then $T$ is normal.

Lemma. Let $\|T\|=1$. Then in the Hilbert space $H$ there exists a sequence $\left\{x_{n}\right\},\left\|x_{n}\right\|=1$ such that

$$
\begin{gathered}
\left\|T^{*} x_{n}\right\| \rightarrow 1 \\
\left\|T^{m} x_{n}\right\| \rightarrow 1 \\
\left\|T^{*} T x_{n}-x_{n}\right\| \rightarrow 0 \\
\left\|T T^{*} x_{n}-x_{n}\right\| \rightarrow 0 \\
\left\|T^{*} T^{m} x_{n}-T^{m-1} x_{n}\right\| \rightarrow 0
\end{gathered}
$$

Proof. We observe that $(1) \Rightarrow(4)$ and $(2) \Rightarrow(3)$. Thus it remains to prove (1), (2), and (5).

By definition there exists a sequence $\left\{x_{n}\right\},\left\|x_{n}\right\|=1$ such that

$$
\left\|T^{*} x_{n}\right\| \rightarrow\left\|T^{*}\right\|=\|T\|=1 .
$$

It is known [3] that for $x,\|x\|=1$ 


$$
\|T x\|^{2} \leqq\left\|T^{2} x\right\| \text {. }
$$

Since

$$
\left\|T^{*} x_{n}\right\|^{2} \leqq\left\|T x_{n}\right\|^{2} \leqq\left\|T^{2} x_{n}\right\| \leqq 1
$$

we have

$$
\lim \left\|T^{2} x_{n}\right\|=1
$$

If

$$
\begin{aligned}
\left\|T^{k-1} x_{n}\right\| & \rightarrow 1 \\
\left\|T^{k} x_{n}\right\| & \rightarrow 1
\end{aligned}
$$

then

$$
\lim \left\|T^{k+1} x_{n}\right\|=1 .
$$

Now

$$
\left\|T^{2} \frac{T^{k-1} x_{n}}{\left\|T^{k-1} x_{n}\right\|}\right\| \geqq\left\|T \frac{T^{k-1} x_{n}}{\left\|T^{k-1} x_{n}\right\|}\right\|^{2}
$$

we have

$$
\left\|T^{k+1} x_{n}\right\| \rightarrow 1 .
$$

By induction we have the relation (2).

For (5) we put

$$
y_{n}(m)=T^{*} T^{m} x-T^{m-1} x_{n}
$$

and

$$
\delta_{n}(m)=\left\|y_{n}(m)\right\|^{2} \text {. }
$$

We have

$$
\begin{aligned}
\delta_{n}(m) & =\left\|T^{*} T^{m} x_{n}\right\|^{2}-2\left\|T^{m} x_{n}\right\|^{2}+\left\|T^{m-1} x_{n}\right\|^{2} \\
& \leqq\left\|T^{m} x_{n}\right\|^{2}-2\left\|T^{m} x_{n}\right\|^{2}+\left\|T^{m-1} x_{n}\right\|^{2} \\
& =\left\|T^{m-1} x_{n}\right\|^{2}-\left\|T^{m} x_{n}\right\|^{2} .
\end{aligned}
$$

By (2) we obtain that $\delta_{n}(m) \rightarrow 0$ for every $m$. This proves the lemma.

Proof of the Theorem 1.2. Let $p$ and $q$ the integers such that $T^{* p} T^{q}$ is a completely continuous operator. By the lemma

$$
T^{*} T^{q} x_{n}-T^{q-1} x_{n} \rightarrow 0
$$

( $\left\{x_{n}\right\}$ is the sequence of lemma). It is clear that $\left\{T^{* p-1} T^{q-1} x_{n}\right\}$ admits a subsequence which is convergent. Also, by the lemma and this 
result we obtain a subsequence of $\left\{T^{* p-2} T^{q-2} x_{n}\right\}$ which is convergent. The process can be repeated and we obtain a subsequence $\left\{x_{n_{k}}\right\}$ of $\left\{x_{n}\right\}$ which is convergent.

Let $x_{0}=\lim x_{n_{k}}$. Thus

$$
\begin{aligned}
& T^{*} T x_{0}=x_{0} \\
& T T^{*} x_{0}=0 .
\end{aligned}
$$

The closed subspace $M_{T}=\left\{x, T T_{x}^{*}=x\right\}$ is a nonzero subspace. By the Lemma 2 of [2] $T$ has a approximate proper value

$$
T y_{n}-\lambda y_{n} \rightarrow 0 \text {. }
$$

The above arguments show that every sequence of approximate eigenvectors $\left\{y_{n}\right\}$ of $T$ belonging to $\bar{\lambda}$ with $|\bar{\lambda}|=1$ contains a convergent subsequence so that $\bar{\lambda}$ is an eigenvalue of $T^{*}$, hence $\lambda$ is of $T$.

Let $M$ be the smallest closed linear subspace which contains every proper subspace of $T$ and $N=M^{\perp}$. It is known that $N$ is invariant for $T^{*}$ and thus $T^{* p} T^{q}$ is completely continuous on $N$. It is known that $T_{N}$ is hyponormal. This shows that $N=\{0\}$ and $M=H$. The theorem is proved.

II. In this section we introduce a class of operators on any Banach space $B$.

Definition 2.1. The operator $T$ is said to be of class $N$ if

$$
x \in B,\|x\|=1 \quad\|T x\|^{2} \leqq\left\|T^{2} x\right\| .
$$

LEMma 2.1. Every hyponormal operator is of class $N$.

Proof.

$$
\|T x\|^{2}=\langle T x, T x\rangle=\left\langle T^{*} T x, x\right\rangle \leqq\left\|T^{*} T x\right\| \leqq\left\|T^{2} x\right\| .
$$

It is clear by this lemma that these operators are extension of a class of hyponormal operators.

Lemma 2.2. If $T$ is of class $N$ and
(1) $\|T\|=1$,
(2) $\left\|x_{n}\right\| \rightarrow 1$,
(3) $\quad\left\|T x_{n}\right\| \rightarrow 1$.

Then $\left\|T^{m} x_{n}\right\| \rightarrow 1(m=1,2,3, \cdots$,$) .$

Proof. This is easy consequence of the inequality

$$
\left\|T^{m} x_{n}\right\|=\left\|T^{2} \cdot T^{m-2} x_{n}\right\| \geqq \frac{\left\|T^{m-1} x_{n}\right\|}{\left\|T^{m-2} x_{n}\right\|} .
$$


Theorem 2.1. If $T$ is of class $N$

$$
\|T\|=\lim \left\|T^{n}\right\|^{1 / n}=\delta_{T} .
$$

Proof. For every $n$, Lemma 2.2. leads to relation $\left\|T^{n}\right\|=\|T\|^{n}$ which gives Theorem 2.1.

COROLLARY 2.1. A generalised nilpotent operator $T$ of the class $N$ is necessarily zero.

Lemma 2.3. If $T$ is of class $N$ on a Hilbert space $H$ and $\|T\|=1$ then

$$
M_{T^{*}}=\left\{x, T T^{*}=x\right\}
$$

is invariant under $T$.

Proof. Let $x \in M_{1^{*}},\|x\|=1$. Then

$$
\begin{aligned}
\left\|T^{*} T x-x\right\|^{2} & =\left\|T^{*} T x\right\|^{2}-2\|T x\|+1 \\
& =\left\|T^{*} T x\right\|^{2}-2\left\|T T T^{*} x\right\|^{2}+1 \\
& =\left\|T^{*} T x\right\|^{2}-2\left\|T^{2} \frac{T^{*} x}{\left\|T^{*} x\right\|}\right\|^{2} \cdot\left\|T^{*} x\right\|^{2}+1 \\
& \leqq\left\|T^{*} T x\right\|^{2}-2\left\|T T^{*} x\right\|^{4} \frac{1}{\left\|T^{*} x\right\|^{2}}+1 \\
& \leqq\left\|T^{*} T x\right\|^{2}-\frac{2}{\left\|T^{*} x\right\|^{2}}+1 \leqq 0 .
\end{aligned}
$$

Thus $\left\|T^{*} T x-x\right\|=0$. It is clear that

$$
T x=T T^{*}(T x)=T\left(T^{*} T x\right)
$$

which shows that $T x \in M_{T^{*}}$.

We observe that $T / M$ is an isometric operator.

THEOREM 2.2 If $T$ is of the class $N$ on a Hilbert space and $T^{*}$ is completely continuous for some $k \geqq 1$ then $T$ is normal.

Proof. (for $\|T\|=1$ ) From the completely continuous property of $T^{k}$ it is clear that the subspace

$$
M_{T^{*}}=\left\{x, T T^{*}=x\right\}
$$

is not $\{0\}$. Also $M_{T^{*}}$ is finite dimensional because it is invariant under $T^{k}$ which is isometric and completely continuous and $M_{T^{*}}$ reduces $T$. We consider the subspace $M_{T^{*}}^{\perp}$ and continue in this way and obtain that $T$ is normal. 
I am indebted to the refere for his suggestions.

\section{REFERENCES}

1. T. Andô, On hyponormal operators, Proc. Amer. Math. Soc. 14 (1963), 290-291.

2. S. Berberian, A note on hyponormal operators, Pacif. J. Math. 12 (1962), 1172-1176.

3. J. Stampfli, Hyponormal operators, Pacif. J. Math. 12 (1962), 1453-58.

Received December 22, 1965.

Institute Mathematics

ROMANIA 



\section{PACIFIC JOURNAL OF MATHEMATICS}

\section{EDITORS}

\section{H. SAMELSON}

Stanford University

Stanford, California

J. P. JANS

University of Washington

Seattle, Washington 98105
J. DUGUNDJI

University of Southern California Los Angeles, California 90007

RICHARD ARENS

University of California

Los Angeles, California 90024

\section{ASSOCIATE EDITORS}
E. F. BECKENBACH
B. H. NEumanN
F. WOLF
K. YosidA

\section{SUPPORTING INSTITUTIONS}

\author{
UNIVERSITY OF BRITISH COLUMBIA \\ CALIFORNIA INSTITUTE OF TECHNOLOGY \\ UNIVERSITY OF CALIFORNIA \\ MONTANA STATE UNIVERSITY \\ UNIVERSITY OF NEVADA \\ NEW MEXICO STATE UNIVERSITY \\ OREGON STATE UNIVERSITY \\ UNIVERSITY OF OREGON \\ OSAKA UNIVERSITY \\ UNIVERSITY OF SOUTHERN CALIFORNIA
}

\author{
STANFORD UNIVERSITY \\ UNIVERSITY OF TOKYO \\ UNIVERSITY OF UTAH \\ WASHINGTON STATE UNIVERSITY \\ UNIVERSITY OF WASHINGTON \\ AMERICAN MATHEMATICAL SOCIETY \\ CHEVRON RESEARCH CORPORATION \\ TRW SYSTEMS \\ NAVAL ORDNANCE TEST STATION
}

Mathematical papers intended for publication in the Pacific Journal of Mathematics should be typewritten (double spaced). The first paragraph or two must be capable of being used separately as a synopsis of the entire paper. It should not contain references to the bibliography. Manuscripts may be sent to any one of the four editors. All other communications to the editors should be addressed to the managing editor, Richard Arens at the University of California, Los Angeles, California 90024.

50 reprints per author of each article are furnished free of charge; additional copies may be obtained at cost in multiples of 50 .

The Pacific Journal of Mathematics is published monthly. Effective with Volume 16 the price per volume ( 3 numbers) is $\$ 8.00$; single issues, $\$ 3.00$. Special price for current issues to individual faculty members of supporting institutions and to individual members of the American Mathematical Society: $\$ 4.00$ per volume; single issues $\$ 1.50$. Back numbers are available.

Subscriptions, orders for back numbers, and changes of address should be sent to Pacific Journal of Mathematics, 103 Highland Boulevard, Berkeley 8, California.

Printed at Kokusai Bunken Insatsusha (International Academic Printing Co., Ltd.), 7-17, Fujimi 2-chome, Chiyoda-ku, Tokyo, Japan.

PUBLISHED BY PACIFIC JOURNAL OF MATHEMATICS, A NON-PROFIT CORPORATION

The Supporting Institutions listed above contribute to the cost of publication of this Journal, but they are not owners or publishers and have no responsibility for its content or policies. 


\section{Pacific Journal of Mathematics

Vol. 22, No. $3 \quad$ March, 1967

Wai-Mee Ching and James Sai-Wing Wong, Multipliers and $H^{*}$

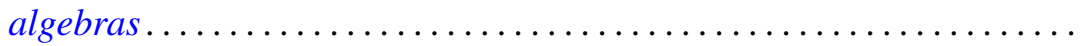

P. H. Doyle, III and John Gilbert Hocking, A generalization of the Wilder

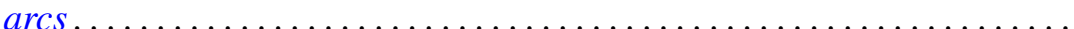

Irving Leonard Glicksberg, A Phragmén-Lindelöf theorem for function

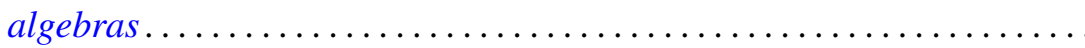

E. M. Horadam, A sum of a certain divisor function for arithmetical semi-groups ..................................... 407

V. Istrăţescu, On some hyponormal operators ................... 413

Harold H. Johnson, The non-invariance of hyperbolicity in partial

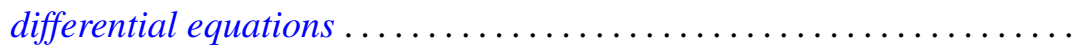

Daniel Paul Maki, On constructing distribution functions: A bounded denumerable spectrum with $n$ limit points................... 431

Ronald John Nunke, On the structure of Tor. II .................... 453

T. V. Panchapagesan, Unitary operators in Banach spaces ............. 465

Gerald H. Ryder, Boundary value problems for a class of nonlinear differential equations ................................. 477

Stephen Simons, The iterated limit condition and sequential convergence .................................... 505

Larry Eugene Snyder, Stolz angle convergence in metric spaces ......... 515 Sherman K. Stein, Factoring by subsets ................... 523

Ponnaluri Suryanarayana, The higher order differentiability of solutions of abstract evolution equations . . .

Leroy J. Warren and Henry Gilbert Bray, On the square-freeness of Fermat and Mersenne numbers ............................... 563

Tudor Zamfirescu, On l-simplicial convexity in vector spaces........... 565 Eduardo H. Zarantonello, The closure of the numerical range contains the spectrum 